\title{
Effects of $\alpha$-tocopherol and ternatin antioxidants on morphology and activation of goat preantral follicles in vitro cultured
}

[Efeitos dos antioxidantes $\alpha$-tocoferol e ternatina na morfologia e na ativação de folículos pré-antrais caprinos cultivados in vitro]

\author{
I.B. Lima-Verde ${ }^{1}$, M.H.T. Matos ${ }^{2}$, J.B. Bruno ${ }^{2}$, F.S. Martins $^{2}$, R.R. Santos ${ }^{2}$, S.N. Báo ${ }^{3}$, M.C.A. Luque ${ }^{3}$, \\ G.A.B. Vieira ${ }^{4}$, E.R. Silveira ${ }^{4}$, A.P.R. Rodrigues ${ }^{2}$, J.R. Figueiredo ${ }^{2}$, M.A.L. Oliveira ${ }^{1}$, P.F. Lima ${ }^{1}$ \\ ${ }^{1}$ Departamento de Medicina Veterinária - UFRPE - Recife, PE \\ ${ }^{2}$ Faculdade de Veterinária - UECE - Fortaleza, CE \\ ${ }^{3}$ Departamento de Biologia Celular - UNB - Brasília, DF \\ ${ }^{4}$ Universidade Federal do Ceará - Fortaleza, CE
}

\begin{abstract}
The effects of $\alpha$-tocopherol and ternatin on the morphology, activation, and growth of goat preantral follicles in vitro cultured, for one or five days, were evaluated. Ovarian fragments were immediately fixed (non-cultured control) or in vitro cultured for one or five days in Minimum Essential Medium (MEM) with or without $\alpha$-tocopherol or ternatin supplementation, both at concentrations of 5,10 , or $15 \mu \mathrm{M}$, corresponding to the following treatments: MEM, TOC5, TOC10, TOC 15, TER5, TER10, and TER15. The percentages of morphologically normal preantral follicles in non-cultured ovarian tissue (control) was $73.2 \%$ and after five days of culture, there was a decrease on these percentages in all treatments $(\mathrm{P}<0.05)$ when compared with non-cultured control. Culture of ovarian cortex for five days increased the percentages of follicular activation in all treatments $(\mathrm{P}<0.05)$. Ultrastructural analysis did not confirm the integrity of caprine preantral follicles cultured for five days in medium containing antioxidants. This study demonstrated that $\alpha$-tocopherol and ternatin can promote follicular activation; however, addition of these antioxidants in the tested concentrations reduced the follicular viability after in vitro culture.
\end{abstract}

Keywords: caprine, preantral follicle, $\alpha$-tocopherol, ternatin

\section{RESUMO}

Os efeitos do $\alpha$-tocoferol e da ternatina sobre morfologia, ativação e crescimento de folículos pré-antrais caprinos cultivados in vitro, por um ou cinco dias, foram avaliados. Os fragmentos ovarianos foram imediatamente fixados (controle não-cultivado) ou cultivados in vitro, por um ou cinco dias, em Meio Essencial Mínimo (MEM) com ou sem suplementação com $\alpha$-tocoferol ou ternatina nas concentrações de 5, 10 ou $15 \mu M$, formando os tratamentos MEM, TOC5, TOC10, TOC 15, TER5, TER10, TER15. O percentual de folículos pré-antrais normais no controle não-cultivado foi de 73,2\%, depois de cinco dias de cultivo, houve redução desse percentual em todos os tratamentos, quando comparados com o controle não-cultivado $(P<0,05)$. O cultivo por cinco dias aumentou a ativação folicular em todos os tratamentos $(P<0,05)$. A análise ultra-estrutural não mostrou folículos pré-antrais íntegros após cinco dias de cultivo em meio contendo antioxidantes. Concluiu-se que o $\alpha$-tocoferol e a ternatina podem promover a ativação folicular, no entanto a adição desses antioxidantes nas concentrações testadas reduziu a viabilidade folicular após o cultivo in vitro.

Palavras-chave: caprino, folículo pré-antral, $\alpha$-tocoferol, ternatina

Recebido em 16 de junho de 2008

Aceito em 15 de outubro de 2008

E-mail: isabel_limaverde@yahoo.com.br 


\section{INTRODUCTION}

The ovarian follicle is the structural and functional unit of the mammalian ovary (McGee et al., 1997), formed by an oocyte surrounded by granulosa cells, basal membrane and, according to their developing stage, theca cells adjacent to basal membrane (Kagawa et al., 2005). Furthermore, most of the follicles $(90 \%)$ present in the ovary are found in the preantral phase (Saumande, 1991). However, during female lifespan, the vast majority is lost by atresia (Mikkelsen et al., 2001), and a limited number (approximately $0.01 \%$ ) of follicles develop until the preovulatory stage. Although follicular atresia naturally occurs in vivo during the whole female reproductive life, as well as during in vitro culture, the complete mechanism responsible for this process is still unknown (Silva et al., 2004).

Many researchers have suggested that follicular atresia can follow the apoptosis pathway (Depalo et al., 2003). Apoptosis is a physiological process (Nakahara et al., 1997), essential to maintain homeostasis (Amsterdan et al., 2003) and can occur as a consequence of different factors, such as oxidative stress (Earle, 2001), which can be explained by the excessive production of reactive oxygen species (ROS) (Bedaiwy et al., 2004). ROS can affect the equilibrium between pro- and anti-oxidant factors in a biological system, leading to a lipidic peroxidation (Romero et al., 1998) and, consequently, cell death. Among the factors controlling ROS production and action, it is possible to include vitamin $\mathrm{E}$ ( $\alpha$-tocopherol) and ternatin, which obstruct the generation of free radicals or remove them when formed (Souza et al., 1999).

The most important biological function of $\alpha$ tocopherol is to protect cell membrane from lipidic peroxidation, avoiding irreversible damages and cellular death (Olson and Seidel Jr., 2000). With regard to ternatin, a bioflavonoid present in Egletes viscosa, it offers hepatic (Souza et al., 1998), gastric (Rao et al., 1997), anti-anaphylactic and anti-inflammatory (Souza et al., 1992) protection, also presenting antioxidant activity (Souza et al., 1999). Thus, since oxidative stress can be one of the factors involved in follicular atresia, the use of antioxidants may contribute for the success of in vitro follicular culture systems. In vitro studies have demonstrated that addition of antioxidants, such as N-acetilcistein, to culture media inhibits apoptosis and/or promotes preantral follicles growth in rat and humans (Tilly and Tilly, 1995; Otala et al., 2002). However, a specific role or the possibility of a dose-dependent action of $\alpha$ tocopherol and ternatin in promoting caprine preantral follicles survival and growth have not been tested.

The aim of this study was to evaluate, by histological and ultrastructural analysis, the effects of $\alpha$-tocopherol and ternatin on morphology, activation, and growth of goat preantral follicles after in vitro culture.

\section{MATERIAL AND METHODS}

Ovaries $(n=6)$ from three adult mixed-breed does were obtained at a local slaughterhouse. The ovaries were washed in $70 \%$ alcohol, twice in $0.9 \%$ saline solution, put into tubes containing $10 \mathrm{~mL}$ of $0.9 \%$ saline solution supplemented with antibiotics, and transported to the laboratory within $1 \mathrm{~h}$ in a thermo flask filled with water at $37^{\circ} \mathrm{C}$.

In the laboratory, the ovaries from each animal were stripped of surrounding fat tissue and ligaments and then cut in half. The medulla, large antral follicles, and corpora lutea were removed. Subsequently, each ovarian pair was divided into 15 fragments of $3 \times 3 \times 1 \mathrm{~mm}$. One fragment was immediately fixed in $10 \%$ formalin for $12 \mathrm{~h}$ and the remaining fragments were in vitro cultured for one or five days at $39^{\circ} \mathrm{C}$ and $5 \% \mathrm{CO}_{2}$, using a 24-well culture dish, each well containing $1 \mathrm{~mL}$ of culture medium. Culture medium consisted of Minimum Essential Medium (MEM) ${ }^{1}$ supplemented with antibiotics ${ }^{2}$ $(100 \mu \mathrm{g} / \mathrm{mL}$ penicillin and $100 \mu \mathrm{g} / \mathrm{mL}$ streptomycin), $\quad 0.25 \mu \mathrm{g} / \mathrm{mL}$ anphotericin $\mathrm{B}^{3}$, $1.4 \mathrm{mg} / \mathrm{mL} \mathrm{BSA}^{3}$ (bovine serum albumine), ITS $^{3}$ (insulin $5 \mu \mathrm{g} / \mathrm{mL}$, transferin $5.5 \mu \mathrm{g} / \mathrm{mL}$, and selenium $5 \eta \mathrm{g} / \mathrm{mL}), 0.23 \mathrm{mM}$ pyruvate $^{3}, 2 \mathrm{mM}$ glutamine $^{3}$, and $2 \mathrm{mM}$ hypoxanthine ${ }^{3}$. This control medium was added or not with different concentrations of $\alpha$-tocopherol ${ }^{3} \quad$ (DL- $\alpha$ -

${ }^{1}$ Cultilab - Rio de Janeiro, Brazil.

${ }^{2}$ Vetec - Rio de Janeiro, Brazil.

${ }^{3}$ Sigma Chemical Co - St. Louis, USA. 
tocopherol - TOC) or ternatin ${ }^{4}$ (TER), both diluted in $95 \%$ alcohol according to Tao et al. (2004). Briefly, hydrophobic $\alpha$-tocopherol and ternatin were first dissolved in $95 \%$ ethanol, stored under the dark at $4^{\circ} \mathrm{C}$, and diluted in maturation medium. The final concentration of antioxidants was 5,10 , or $15 \mu \mathrm{M}$ and the final concentration of ethanol in the culture medium was less than $0.05 \%$. Treatments were named MEM, TOC5, TOC10, TOC15, TER5, TER10, and TER 15 and concentrations of $\alpha$-tocopherol were selected based on previous studies obtained from the literature (Kusakabe and Kamiguchi, 2004; Tao et al., 2004). In regard to ternatin, no reports were found showing cellular culture with this substance, then it was decided to use the same concentrations of $\alpha$-tocopherol. Every two days, the culture medium was replaced by fresh medium. Each treatment was repeated three times, thus using the ovaries of three different animals.

After fixation in $10 \%$ formalin for $12 \mathrm{~h}$, ovarian fragments were dehydrated in ethanol, clarified with xylene, and embedded in paraffin wax. Serial sections $(7 \mu \mathrm{m})$ of ovarian tissue were cut and every fifth section was mounted on glass slides and stained with periodic acid Schiff (PAS)-hematoxylin ${ }^{3}$. All sections were examined using a light microscope $\mathrm{e}^{5}$ at $400 \mathrm{X}$ magnification.

Preantral follicles were defined as follicles with an oocyte surrounded either by one flattened (primordial follicles) and/or cuboidal layer or several layers of only cuboidal granulosa cells (developing follicles). To avoid counting a follicle more than once, preantral follicles were counted only in the sections where their oocyte nucleus was observed. Follicular quality was evaluated based on the morphological integrity of the oocyte and granulosa cells. Preantral follicles were also classified as: (i) histologically/morphologically normal, when they contained an intact oocyte and intact granulosa cells; and (ii) degenerated, when their oocyte nucleus had become pycnotic and the oocyte was shrunken or when possibly granulosa cells had detached from the basement membrane and have enlarged in volume. A minimum of 50 follicles were counted in each repetition (150 per

${ }^{4}$ Obtained from Dr. Edilberto Silveira - Universidade Federal do Ceará - Fortaleza, Brazil.

${ }^{5}$ Electron Microscopy Sciences - Washington, USA. treatment), being evaluated a total of 2,250 preantral follicles.

To evaluate follicular activation, the number of normal primordial and developing follicles was counted before and after in vitro culture. In addition, follicular diameter was taken using only normal follicles from day 0 (control) and after in vitro culture for one or five days, in all groups. Follicular diameter was measured by determining the mean of two perpendicular diameters using a calibrated ocular micrometer in twenty follicles for each treatment.

At the ultrastructural analysis, tissue fragments with a maximum dimension of $1 \mathrm{~mm}^{3}$ were fixed in $2 \%$ paraformaldehyde $e^{5}$ and $2.5 \%$ glutaraldehyde $^{5}$ in $0.1 \mathrm{M}$ sodium cacodylate buffer $^{5}$ ( $\mathrm{pH}$ 7.2). After fixation, specimens were post-fixed in $1 \%$ osmium tetroxide $5,0.8 \%$ potassium ferricyanide 5 , and $5 \mathrm{mM}$ calcium chloride $^{5}$ in $0.1 \mathrm{M}$ sodium cacodylate buffer ${ }^{5}$ for 1h. Subsequently, samples were dehydrated in a gradient of acetone ${ }^{3}$ solutions (30-100\%) and the tissues were embedded in Spurr ${ }^{5}$. Semi-thin sections $(3 \mu \mathrm{m})$ were stained with toluidine blue for light microscopy. The ultra-thin sections (60$70 \mathrm{~nm})$ were contrasted with uranyl acetate and lead citrate, and examined under a transmission electron microscope ${ }^{6}$, operating at $80 \mathrm{kV}$. At ultrastructural evaluation, cytoplasmic organelles and basement membrane integrity were observed, as well as the presence of vacuolization.

For the statistical analysis, data from 2,250 preantral follicles were analyzed using a completely randomized design with 15 treatments, represented by control group and three different culture media containing MEM with or without antioxidants ( $\alpha$-tocopherol or ternatin) in different concentrations $(5,10$, or $15 \mu \mathrm{M})$ and days of culture (one or five). Three replicates were used, being observed 150 follicles per treatment. Data for follicular diameter were submitted to analysis of variance and means were compared using Bonferroni's test. Percentages of morphologically normal and developing preantral follicles were compared by chi-square test. Differences among groups were considered significant when $\mathrm{P}<0.05$.

${ }^{6}$ Jeol JEM- 1011 - Tokyo, Japan. 


\section{RESULTS}

Classical histology showed that there were morphologically normal and degenerated follicles before and after in vitro culture for one or five days. At histological sections, goat preantral follicles appeared morphologically normal when oocyte was spherical or slightly elongated, with a central nucleus and, sometimes, with a visible nucleolus. Granulosa cells were well distributed around the oocyte (Fig. 1). Regarding to degenerated follicles, it was observed piknotic oocyte nuclei, cytoplasmic retraction, swelling and disorganized granulosa cells around oocyte.
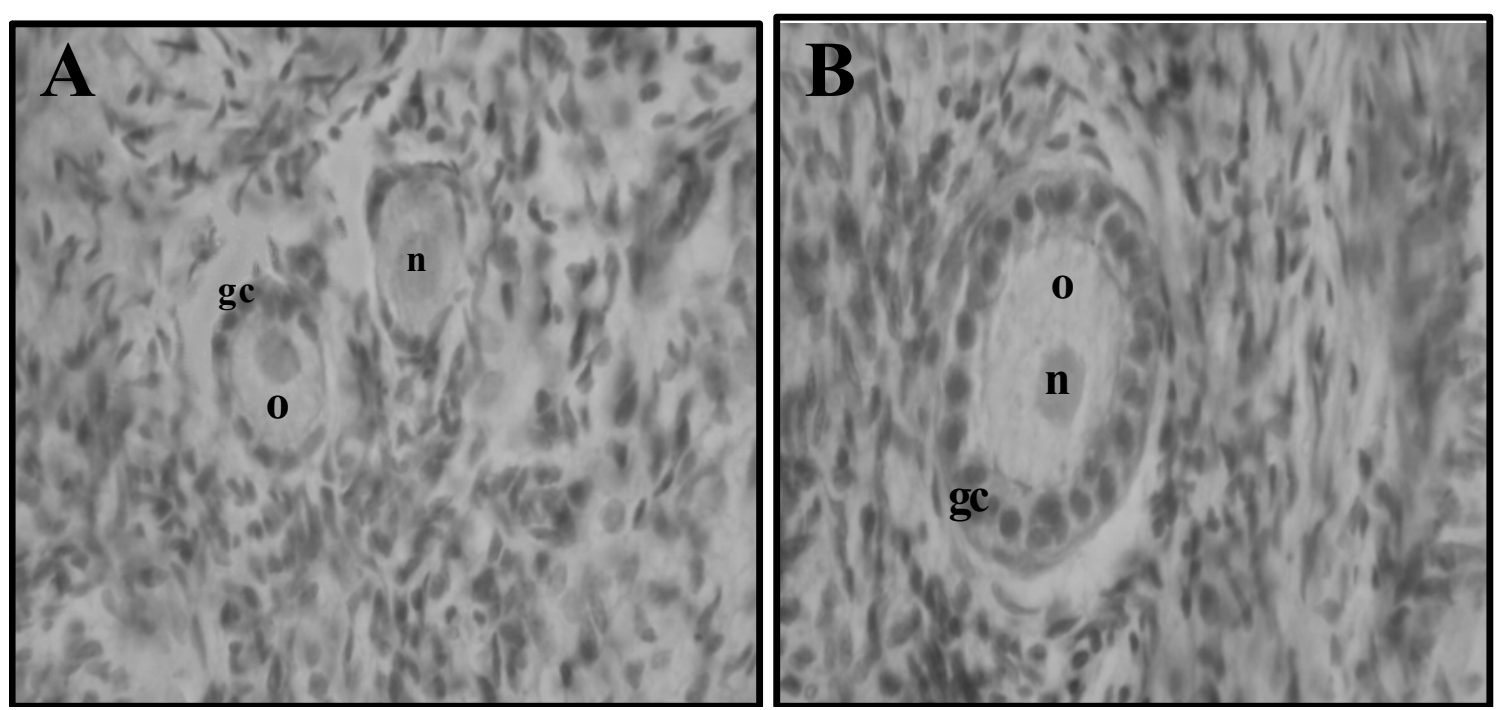

Figure 1. Histological sections (400X) of ovarian tissue cultured for five days in $5 \mu \mathrm{M}$ of $\alpha$-tocopherol (A) or ternatin (B) showing normal follicles. o: oocyte; n: nucleus; gc: granulosa cells.

The percentages of morphologically normal preantral follicles in non-cultured ovarian tissue (control) was $73.2 \%$ and the in vitro culture promoted a decrease on the percentages of morphologically normal preantral follicles in all treatments $(\mathrm{P}<0.05)$ when compared with control. Addition of $10 \mu \mathrm{M}$ of $\alpha$-tocopherol on day one of culture and $15 \mu \mathrm{M}$ of $\alpha$-tocopherol or ternatin on days one or five of culture significantly reduced the percentage of morphologically normal preantral follicles $(\mathrm{P}<0.05)$ compared to follicles cultured with MEM without supplements (Table 1). On day one of culture, when the antioxidants were compared at the same concentration, the percentage of normal preantral follicles was significantly higher $(\mathrm{P}<0.05)$ in ternatin when compared with $\alpha$-tocopherol, both at $10 \mu \mathrm{M}$. Independently of the treatment, no effect of culture period (one or five days) on the rates of morphologically normal preantral follicles was observed.
Table 1. Percentage of morphologically normal goat preantral follicles in control (non-cultured) and after culture for one or five days in presence or absence of $\alpha$-tocopherol or ternatin

\begin{tabular}{c|cc}
\hline Treatment & $\begin{array}{c}\text { D1 }(\%) \\
\text { (one day } \\
\text { of culture) }\end{array}$ & $\begin{array}{c}\text { D5 }(\%) \\
\text { (five days of } \\
\text { culture) }\end{array}$ \\
\hline MEM & $50.7 \mathrm{~A}$ & $40.0 \mathrm{~A}$ \\
TOC5 & $40.7 \mathrm{Aa}$ & $37.3 \mathrm{Aa}$ \\
TOC10 & $32.0 \mathrm{Ba}$ & $29.3 \mathrm{Aa}$ \\
TOC15 & $27.3 \mathrm{Ba}$ & $23.3 \mathrm{Ba}$ \\
TER5 & $51.3 \mathrm{Aa}$ & $43.3 \mathrm{Aa}$ \\
TER10 & $44.0 \mathrm{Ab}$ & $33.3 \mathrm{Aa}$ \\
TER15 & $32.7 \mathrm{Ba}$ & $26.7 \mathrm{Ba}$ \\
\hline
\end{tabular}

A,B significantly differs from MEM without supplements in each day of culture $(\mathrm{P}<0.05)$.

a,b significantly differs between $\alpha$-tocopherol and ternatin at same concentration and day of culture $(\mathrm{P}<0.05)$.

MEM: Minimal Essencial Medium supplemented; TOC5: $5 \mu \mathrm{M} \alpha$-tocopherol; TOC10: $10 \mu \mathrm{M} \alpha$-tocopherol; TOC15: $15 \mu \mathrm{M} \alpha$-tocopherol; TER5: $5 \mu \mathrm{M}$ ternatin; TER10: $10 \mu \mathrm{M}$ ternatin; TER15: $15 \mu \mathrm{M}$ ternatin. 
Fig. 2 shows the percentages of developing follicles in non-cultured ovarian tissue (control) and cultured for one or five days. In vitro culture promoted a significant increase $(\mathrm{P}<0.05)$ on the percentage of developing follicles when compared to control. In regard to MEM, addition of antioxidants to the culture medium did not affect follicular activation $(\mathrm{P}>0.05)$, except on day one of culture when $5 \mu \mathrm{M}$ of $\alpha$-tocopherol and $15 \mu \mathrm{M}$ ternatin were used. On day five of culture, MEM supplemented or not with $10 \mu \mathrm{M}$ of ternatin increased $(\mathrm{P}<0.05)$ follicular activation when compared to the others treatments. No difference was observed when it was compared to $\alpha$-tocopherol and ternatin at same concentration and day of culture.

Fig. 3 shows follicular diameter in non-cultured and in vitro cultured ovarian cortex for one or five days. When compared with control, only on day one of culture, a decrease $(\mathrm{P}<0.05)$ in the follicular diameter was observed when $15 \mu \mathrm{M}$ of $\alpha$-tocopherol was used.



*significantly differs from control $(\mathrm{P}<0.05)$.

A,B significantly differs from MEM without supplements in each day of culture $(\mathrm{P}<0.05)$.

a,b significantly differs between culture period ( 1 and 5 days) $(\mathrm{P}<0.05)$.

MEM: Minimal Essencial Medium supplemented; TOC5: $5 \mu \mathrm{M} \alpha$-tocopherol; TOC10: 10 $\mu \mathrm{M} \alpha$-tocopherol; TOC15: $15 \mu \mathrm{M} \alpha$ tocopherol; TER5: $5 \mu \mathrm{M}$ ternatin; TER10: $10 \mu \mathrm{M}$ ternatin; TER15: $15 \mu \mathrm{M}$ ternatin.

Figure 2. Percentage of developing goat preantral follicles in control (non-cultured) and after culture for one or five days in presence or absence of $\alpha$-tocopherol or ternatin.

\section{Day $1 \square$ Day 5}

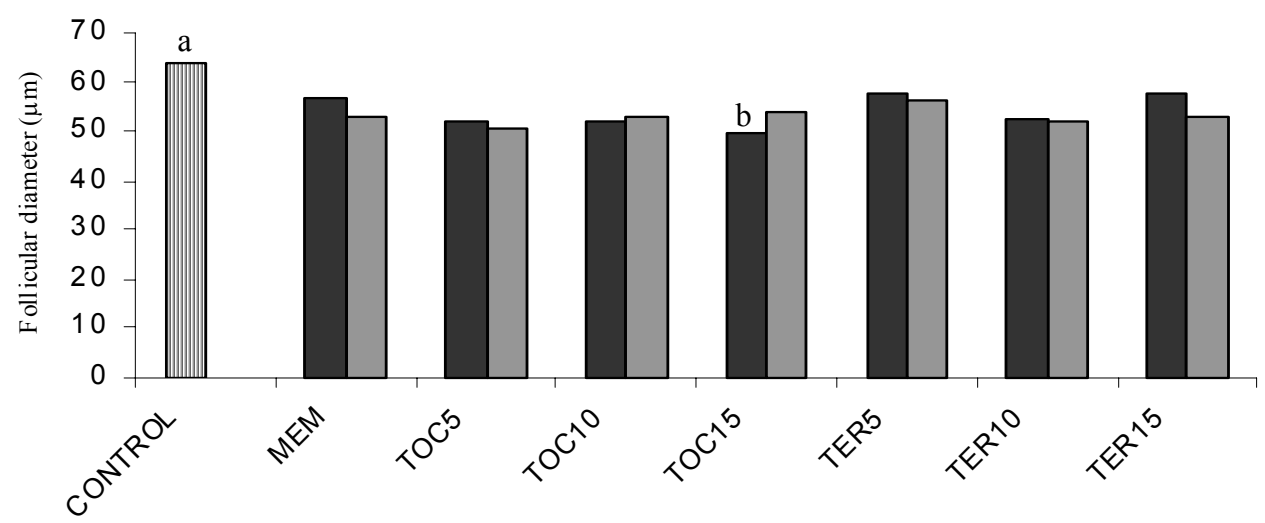

Treatments

a,b significantly differs from control $(\mathrm{P}<0.05)$.

MEM: Minimal Essencial Medium supplemented; TOC5: $5 \mu \mathrm{M} \alpha$-tocopherol; TOC10: $10 \mu \mathrm{M} \alpha$-tocopherol; TOC15: $15 \mu \mathrm{M} \alpha$ tocopherol; TER5: $5 \mu \mathrm{M}$ ternatin; TER10: $10 \mu \mathrm{M}$ ternatin; TER15: $15 \mu \mathrm{M}$ ternatin.

Figure 3. Mean follicular diameter $(\mu \mathrm{m})$ of goat preantral follicles in control (non-cultured) and after culture for one or five days in presence or absence of $\alpha$-tocopherol or ternatin. 

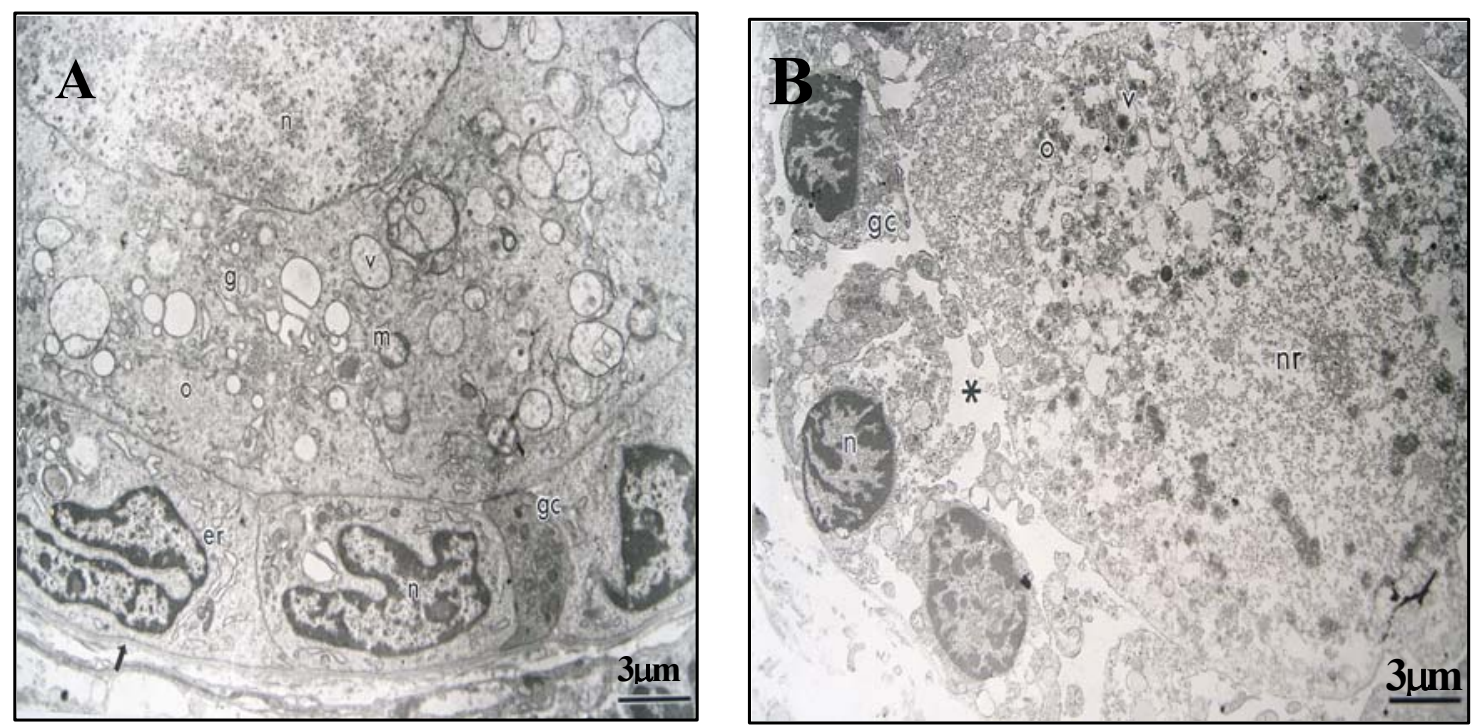

Figure 4. Ultrastructural analysis (4200X) of non-cultured preantral follicle (A) and cultured for five days in $5 \mu \mathrm{M}$ of $\alpha$-tocopherol (B). n: nucleus; m: mitochondria; er: endoplasmatic reticulum; g: Golgi complex; v: vesicles; o: oocyte; gc: granulosa cells; arrow: basal membrane; nr: nuclear region; *: empty space.

\section{DISCUSSION}

It is known that mechanisms and factors involved in the regulation of early folliculogenesis and follicular atresia are not well understood. In the present study, caprine preantral follicles in ovarian cortical tissue were in vitro cultured for up to five days in the presence of antioxidant substances to verify their effects on follicular viability and development. Normal and degenerated preantral follicles were observed in non-cultured ovarian tissue and in tissue cultured for one or five days in different treatments. Light microscopical analysis showed normal and degenerated preantral follicles. Otala et al. (2002) reported, in human ovarian tissue cultured for 8,24 , and $48 \mathrm{~h}$ with antioxidant $\mathrm{N}$ acetilcistein, the same changes verified in this study. Similar findings were also observed after in vitro culture of preantral follicles in caprine (Silva et al., 2004), murine (Nilsson and Skinner, 2004), and ovine (Andrade et al., 2005) or after criopreservation in caprine (Celestino et al., 2007).

It was observed a significant reduction in the percentage of morphologically normal preantral follicles since the first day of culture in all treatments with antioxidants, regardless of the medium used. In both culture periods (one or five days), it was observed that culture with
MEM without supplements or with $5 \mu \mathrm{M}$ of $\alpha$ tocopherol or ternatin resulted in a higher percentage of normal follicles when compared to other treatments using antioxidants. Recently, some in vitro studies have showed the importance of antioxidants addition in cellular culture to reduce the injuries that normally occurs due to the production of ROS from normal cellular metabolic reaction (Murray et al., 2001; Tao et al., 2004). It is known that free radicals, for instance, hydrogen peroxide $\left(\mathrm{HO}_{2}{ }^{\circ}\right)$, superoxide anion $\left(\mathrm{O}_{2}^{-}\right)$, and hydroxyl radical $(\mathrm{OH})$, are responsible for lipidic peroxidation of polyunsaturated fatty acid of cellular membranes (Povalishev et al., 2006), leading to injuries and cellular death. Antioxidants, such as $\alpha$ tocopherol and ternatin, have been successfully used to reduce these deleterious changes. Tao et al. (2004) observed that $10 \mu \mathrm{M}$ of $\alpha$-tocopherol reduced cumulus cell DNA fragmentation and promoted oocyte development up to the metaphase II stage. With regard to ternatin, Souza et al. (1999) verified that this substance inhibits lipidic peroxidation and affords protections against liver damage induced by aflatoxin B1.

The addition of antioxidants to the culture medium did not improve follicular viability. The differences between these results from other results may be due to the type and concentration 
of substance used for antioxidants dilution, as well as different species and methodologies used. Kusakabe and Kamiguchi (2004) showed that dimetilsulphoxyde might be utilized for dilution without damage in cell culture. However, in this work, it was used ethanol $95 \%$ based in satisfactory results obtained with in vitro culture of embryos in different species (murine: Tsujii et al., 2002; and bovine: Olson and Seidel Jr., 2000) and in porcine oocytes (Tao et al., 2004). Antioxidants may act as a pro-oxidant at high concentrations after a certain period and $\alpha$ tocopherol has an antioxidant action for a short period of time, then rapidly reacts with oxidant species and forms free radicals (Sen et al., 2006). Some authors showed that some flavonoids could have oxidative action depending on the concentration (Sadeghipour et al., 2005). Transferin and selenium, used as supplements of the culture medium, may act as antioxidant and probably increase pro-oxidants properties of these substances.

Results showed that caprine preantral follicles could be activated since the first day of culture in the presence of different concentrations of $\alpha$ tocopherol and ternatin. They are in accordance with many studies in which preantral follicles were cultured in the presence of relaxin in humans (Shirota et al., 2005), epidermal growth factor (EGF) and 3-indol-acetic acid (IAA) in ovine (Andrade et al., 2005), kit-ligand (KL) and fibroblast growth factor (FGF) in mouse (Nilsson and Skinner, 2004), and coconut water in caprine (Silva et al., 2004; Martins et al., 2005). In regard to follicular growth, in both culture period, all treatments were similar when compared to control and among them, except follicles cultured with $15 \mu \mathrm{M}$ of $\alpha$-tocopherol, which showed a reduction of follicular diameter after one day of culture. These results can be due to the onset of degeneration, which was not recognizable at histological evaluation.

Some authors have emphasized the importance of TEM studies of follicles after their in vitro culture, since they gave close insight into the ultrastructural characteristics of follicles, which could help to avoid too optimistic opinions about the quality of cultured follicles based on light microscopic investigations (Van den Hurk et al., 1998; Salehnia et al., 2002). These current findings thus confirm this latter view. In regard to ultrastructural findings, degenerated preantral follicles were observed, in all treatments with $\alpha$ tocopherol and ternatin after five days of culture. These changes were not observed in non-cultured preantral follicles as well as in those cultured only with MEM up to five days. The ultrastructural changes in this study were similar to the signs of apoptosis in fresh (De Pol et al., 1997) and in vitro cultured (Otala et al., 2002) human preantral follicles.

In conclusion, this study demonstrated that $\alpha$ tocopherol and ternatin could promote follicular activation, although the addition of antioxidants in the tested concentrations reduced the follicular viability after in vitro culture.

\section{ACKNOWLEDGEMENTS}

This work was supported by Fundação Cearense de Apoio à Pesquisa (FUNCAP). Isabel Bezerra Lima-Verde was a recipient of a grant from this institution. The authors also thank Dr. José Roberto Viana Silva for suggestions in preparing the manuscript.

\section{REFERENCES}

AMSTERDAN, A.; KEREN-TAL, I.; AHARONI, D. et al. Steroidogenesis and apoptosis in the mammalian ovary. Steroids, v.68, p.861-867, 2003.

ANDRADE, E.R.; SENEDA, M.M.; ALFIERI, A.A. et al. Efeito da concentração de ácido 3indol-acético na ativação e crescimento in vitro de folículos pré-antrais ovinos. Arq. Bras. Med. Vet. Zootec., v.57, p.334-339, 2005.

BEDAIWY, M.A.; FALCONE, T.; MOHAMED, M.S. et al. Differential growth of human embryos in vitro: role of reactive oxygen species. Fertil. Steril., v.82, p.593-600, 2004.

CELESTINO, J.J.H.; SANTOS, R.R.; MARTINS, F.S. et al. Conservação de folículos pré-antrais bovinos em solução salina $0,9 \%$ ou TCM 199. Arq. Bras. Med. Vet. Zootec., v.59, p.591-599, 2007.

DE POL, A.; VACCINA, F.; FORABOSCO, A. et al. Apoptosis of germ cells during preantral oogenesis. Hum. Reprod., v.12, p.2235-2241, 1997.

DEPALO, R.; NAPPI, L.; LOVERRO, G. et al. Evidence of apoptosis in human primordial and 
primary follicles. Hum. Reprod., v.18, p.26782682, 2003.

EARLE, K.E. Nutrientes antioxidantes: seu papel em uma dieta saudável. Temas Vet., v.3, p.3-9, 2001.

KAGAWA, N.; KUWAYAMA, M.; MIYANO, $\mathrm{T}$. et al. Growth and maturation of follicles and oocytes following xenotransplantation of porcine ovarian tissues and in vitro maturation. $J$. Reprod. Dev., v.51, p.741-748, 2005.

KUSAKABE, H.; KAMIGUCHI, Y. Ability to activate oocytes and chromosome integrity of mouse spermatozoa preserved in EGTA Tris$\mathrm{HCl}$ buffered solution supplemented with antioxidants. Theriogenology, v.62, p.897-905, 2004.

MARTINS, F.S.; VAN DEN HURK, R.; SANTOS, R.R. et al. Development of goat primordial follicles after in vitro culture of ovarian tissue in Minimal Essencial Medium supplemented with coconut water. Anim. Reprod., v.2, p.106-113, 2005.

McGEE, E.A.; PERLAS, E.; LAPOLT, P.S. et al. Follicle-stimulating hormone enhances the development of preantral follicles in juvenile rats. Biol. Reprod., v.57, p.990-998, 1997.

MIKKELSEN, A.L.; HOSTAND, E.; LINDENBERG，S. Incidence of apoptosis in granulosa cells from immature human follicles. Reproduction, v.122, p.481-486, 2001.

MURRAY, A.A.; MOLINEK, M.D.; BAKER, S.J. et al. Role of ascorbic acid in promoting follicle integrity and survival in intact mouse ovarian follicles in vitro. Reproduction, v.121, p.89-96, 2001.

NAKAHARA, T.; ISHII, K.; TANAKA, Y. et al. Flow-dependent regulation of nitric oxide formation in the isolated canine mesenteric arterial bed. Jpn. J. Pharm., v.74, p.275-280, 1997.

NILSSON, E.E.; SKINNER, M.K. Kit ligand and basic fibroblastic growth factor interaction in the induction of ovarian primordial to primary follicle transition. Mol. Cell. Endocr., v.214, p.19-25, 2004.

OLSON, S.E.; SEIDEL JR., G.E. Culture of in vitro-produced bovine embryos with vitamin $\mathrm{E}$ improves development in vitro and after transfer to recipients. Biol. Reprod., v.62, p.248-252, 2000.

OTALA, M.; ERKKILA, K.; TUURI, T. et al. Cell death and its suppression in human ovarian tissue culture. Mol. Hum. Reprod., v.8, p.228236, 2002.

POVALISHEV, V.N.; POLOZOV, G.I.; SHADYRO, O.I. Effects of $\alpha$-tocopherol and related compounds on reactions involving various organic radicals. Bioorg. Med. Chem. Letters, v.16, p.1236-1239, 2006.

RAO, V.N.S.; SANTOS, F.A.; SOBREIRA, T.T. et al. Investigations on the gastroprotective and antidiarrhoeal properties of ternatin, a tetramethoxyflavone from Egletes viscosa. Planta Med., v.63, p.146-149, 1997.

ROMERO, F.J.; BOSCH-MORELL, F.; ROMERO, M.J. et al. Lipid peroxidation products and antioxidants in human disease. Environ. Health Persp., v.106, p.1229-1234, 1998.

SADEGHIPOUR, M.; TERREUX, R.; PHIPPS, J. Flavonoids and tyrosine nitration: structure activity relationship correlation with enthalpy of formation. Toxicol. in Vitro, v.19, p.155-165, 2005.

SALEHNIA, M.; MOGHADAM, E.A.; VELOJERDI, M.R. Ultrastructure of follicles after vitrification of mouse ovarian tissue. Fertil. Steril., v.78, p.644-645, 2002.

SAUMANDE J. La folliculogenèse chez les ruminants. Rech. Vet., v.167, p.205-218, 1991.

SEN, C.K.; KHANNA, S.; ROY, S. Tocotrienols: vitamin E beyond tocopherols. Life Sci., v.78, p.2026-2032, 2006.

SHIROTA, K.; TATEISHI, K.; KOJI, T. Early human preantral follicles have relaxin and relaxin receptor (LGR7), and relaxin promotes their development. J. Clin. Endocr. Methods, v.90, p.516-521, 2005.

SILVA, J.R.V.; VAN DEN HURK, R.; COSTA, S.H.F. et al. Survival and growth of goat primordial follicles after in vitro culture of ovarian cortical slices in media containing coconut water. Anim. Reprod. Sci., v.81, p.273286, 2004.

SOUZA, M.F.; RAO, V.S.N.; SILVEIRA, E.R. Antianaphylactic and antiinflamatory effects of 
ternatin, a flavonoid isolated from Egletes viscosa Less. Braz. J. Med. Biol. Res., v.25, p.1029-1032, 1992.

SOUZA, M.F.; RAO, V.S.N.; SILVEIRA, E.R. Prevention of acetaminophen-induced hepatotoxicity by ternatin, a bioflavonoid from Egletes viscosa Less. Phytof. Res., v.12, p.557561, 1998.

SOUZA, M.F.; TOMÉ, A.R.; RAO, V.S. Inhibition by the bioflavonoid ternatin of aflatoxin B1- induced lipid peroxidation in rat liver. J. Pharm. Pharmacol., v.51, p.125-129, 1999.

TAO, Y.; ZHOU, B.; XIA, G. et al. Exposure to L-ascorbic acid or $\alpha$-tocopherol facilitates the development of porcine denuded oocytes from metaphase I to metaphase II and prevents cumulus cells from fragmentation. Reprod. Dom. Anim., v.39, p.52-57, 2004.

TILLY, J.L.; TILLY, K.I. Inhibitors of oxidative stress mimic the ability of follicle-stimulating hormones to suppress apoptosis in cultured rat ovarian follicles. Endocrinology, v.136, p.242$252,1995$.

TSUJI, H.; MURANAKA, M.; HAMANO, K. Culture of in vitro mouse embryos with vitamin E improves development. J. Reprod. Dev., v.48, p.25-29, 2002.

VAN DEN HURK, R.; SPEK, E.R.; HAGE, W.J. Ultrastructure and viability of isolated bovine preantral follicles. Hum. Reprod., v.4, p.833-841, 1998. 